\title{
Acinar Adenocarcinoma of Prostate with Predominant TTF-1 Positive Intraductal Component
}

\author{
Banu SARSIK', Nisar KARADENIZ'1, Adnan ŞiMŞíR', Rahmi AKYOL', Kutsal YÖRÜKOĞLU², Sait ŞEN'
}

Department of Pathology, ${ }^{1}$ Ege University, Faculty of Medicine, IZMIR, TURKEY, ${ }^{2}$ Dokuz Eylül University, Faculty of Medicine, IZMiR, TURKEY

\begin{abstract}
Intraductal carcinoma of prostate has been previously described in radical prostatectomies. It's rarely encountered in needle biopsies in the absence of infiltrative carcinoma. But, both histogenesis and nomenclature of the lesion is still controversial. Among the pure intraductal carcinoma of prostate cases, a different solid patern was described with smaller nuclei at the center of the ducts. However, there is a lack of information about the association of those cases with acinar prostate adenocarcinoma. Herein, we describe a case of acinar adenocarcinoma with predominant non-neuroendocrine TTF-1 positive small cell intraductal component.
\end{abstract}

Key Words: Prostate neoplasms, Ductal carcinoma, Thyroid transcription factor-1

\section{INTRODUCTION}

Intraductal carcinoma of prostate (IDC-P) has been previously described in radical prostatectomies (1-5). Both histogenesis and nomenclature of the lesion is still controversial and it's rarely encountered in needle biopsies in the absence of infiltrative carcinoma. But it is important to differentiate these lesions from high grade prostatic intraepithelial neoplasia (HG-PIN) especially in needle biopsies for a proper prognostic information and therapeutic decision. A separate variant has been described among pure IDC-P cases which are characterized by more solid small cell areas in the center of the ducts compared with the periphery (6). However, less is known about the association of this variant with acinar prostate adenocarcinoma.

Thyroid transcription factor-1 (TTF-1) positivity has been reported in tumors of many organs such as lung, thyroid and gastrointestinal tractus but it is rarely seen in prostate. The reported cases are TTF-1 positive small cell neuroendocrine cell carcinoma accompanied by acinar prostate adenocarcinoma (7-9). We report a case of acinar adenocarcinoma with predominant non-neuroendocrine TTF-1 positive small cell intraductal component.

\section{CASE REPORT}

A 72-year-old male was attended to the hospital with complaints of urination. Transrectal ultrasound which was performed upon finding a high PSA value as $500 \mathrm{ng} / \mathrm{ml}$, revealed a heterogeneous glandular structure with capsule calcifications. Core needle biopsy confirmed the presence

(Turk Patoloji Derg 2017, 33:70-73)

Received : 22.12.2012 Accepted : 12.03.2013 of a carcinoma. However, radical surgery could not be performed because of extensive bone metastases. He has begun to receive antiandrogen therapy and radiotherapy, but unfortunately the patient died six months after the diagnosis.

Sectioning, hematoxylin-eosin staining and immunohistochemistry of the tumor were performed according to standard protocols. Chromogranin A (Neomarker, cocktail), p63 (Neomarker, 4A4), synaptophysin (Novocastro, 27G12), CD56 (Cell Marque, 123C3.D5), thyroid transcription factor-1 (Novocastro, SPT24) and Ki67 (DAKO, MIB-1) were detected by mouse monoclonal antibodies, whereas AMACR (Neomarker, 13H4) was detected by monoclonal rabbit antibody. IHC staining process took place on the BenchMark XT fully automatic immunohistochemistry staining device.

Prostate carcinoma was identified in 10 of the 12 core biopsy specimens. Tumor was characterized by two separate histological features: (1) high grade infiltrating acinar adenocarcinoma with Gleason score 8 or 9 (2) intraductal carcinoma which was characterized by malign epithelial cells filling dilated ductal-acinar structures surrounded by basal cells (Figure 1A-B). Interestingly, the cells in the center of dilated ducts were smaller and more benign-looking than the cells of the peripheral parts of the dilated duct (Figure 1C). Immunhistochemical analysis with chromogranin, synaptophysin and CD56 failed to show a neuroendocrine differentiation in these cell and the peripheral parts of IDC-P as well as acinar adenocarcinoma

Correspondence: Banu SARSIK

Ege Üniversitesi, Tip Fakültesi, Patoloji Anabilim Dalı,

Bornova, İZMIR, TURKEY

E-mail: banu.sarsik@ege.edu.tr Phone: +90 5053900991 
component. Ki67 was also negative in the small cell areas of IDC-P. The peripheral located neoplastic cells exhibited positivity for only AMACR (Figure 1D,E) while the neoplastic cells within the center were only positive for TTF-1 (Figure 1F). Basal cells showed p63 positivity in the IDC-P component (Figure 1D,E). Also some cells in the acinar adenocarcinoma component exhibited positivity for TTF-1 (Figure 1F).

\section{DISCUSSION}

The histogenesis of intraductal carcinoma of prostate (IDC-P) is still unclear. Mainly two hypotheses were proposed. The first one regards the possibility of invasion of adjacent benign prostatic ducts and acini by a high grade
(Gleason score 8 or 9) acinar adenocarcinoma. The other one assumes the development of de novo IDC-P from high grade PIN. The first mechanism is favored since IDC-P is consistently associated with a component of high grade invasive carcinoma $(3-5,10)$. Dawkins et al also recently demonstrated similar loss of heterozygosity frequencies in both IDC-P and higher Gleason grade prostate cancers favoring a common origin (11).

Recent studies have revealed the TMPRSS2-ERG gene fusion in prostate cancers. This gene fusion is seen IDC-P and more aggressive prostate cancer which are all favoring the first theory. (12-14) In a large core needle biopsy series, Guo and Epstein reported 27 pure IDC-P cases

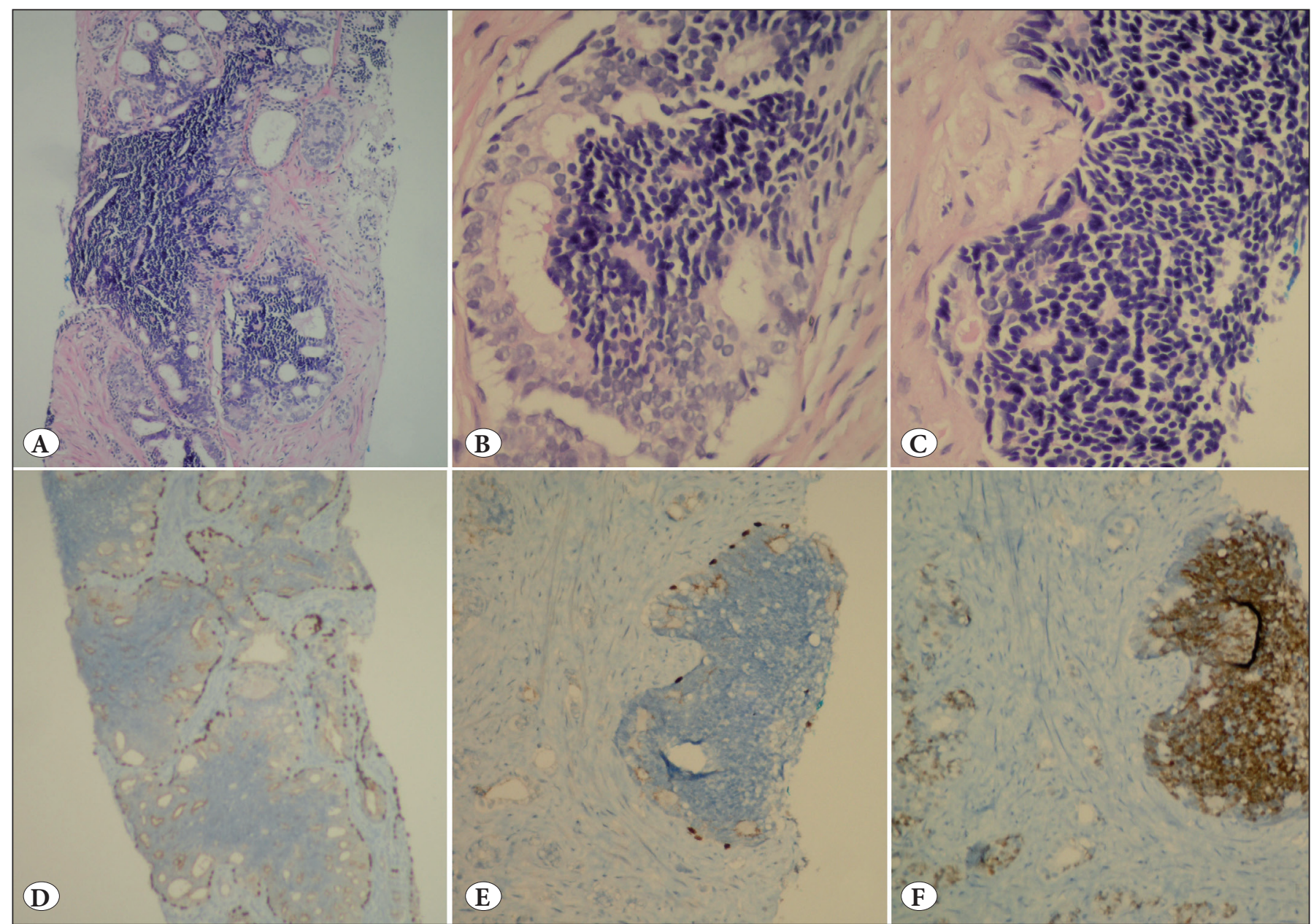

Figure 1: A,B) Infiltrating acinar adenocarcinoma with Gleason score 8 or 9 and intraductal carcinoma that was characterized by malignant epithelial cells filling dilated ductal-acinar structures surrounded by basal cells (A;H\&E; x10, B; H\&E; x40). C) The cells in the center of dilated ducts were smaller and more benign-looking than the cells of the peripheral parts of the duct (H\&E; $x 40)$. D,E) The neoplastic cells of the peripheral part of the duct exhibited cytoplasmic positivity for AMACR and basal cells showed p63 nuclear positivity in the IDC-P component (dual with p63 and AMACR, D; x10, E; x20). F) The neoplastic cells within the center of the dilated duct and some cells in the acinar adenocarcinoma component exhibited positivity for TTF1 (TTF1; x40). 
without infiltrative adenocarcinoma, six of which were diagnosed as Gleason score 8 or 9 high grade infiltrative cancer in their subsequent radical prostatectomies (6). Among these 27 cases, nine showed similar central located small cell component as in our case. Regarding the second hypothesis, Cohen et al reported a distinct variant of IDC-P accompanying extensive HG-PIN (15). They found a close spatial association between IDC-P and HG-PIN with continuing lumens suggestive of a IDC-P arising in areas of HG-PIN. (15). However, the mechanisms of carcinogenesis in prostate carcinoma as well as how HG-PIN progress to IDC-P is still unclear (16).

In our case, we observed a high grade prostatic acinar adenocarcinoma accompanied by an extensive morphologically and immunhistochemically similar to intraductal component. Intraductal component showed prominent small cells. Both components expressed TTF-1 positivity but lacked neuroendocrine differentiation. According to Wang and Epstein, negative stains for neuroendocrine markers should not exclude the diagnosis of small cell carcinoma as long as the morphology on routinely stained sections is diagnostic (7). However, in our case, small cell carcinoma was excluded by both negativity of neuroendocrine markers and also on morphological grounds as the central located small cells lacked the histologic malignancy criteria described for these tumors. There are few reports related to TTF1 expression in the tumors of prostate tissue. Leite et al found that TTF-1 was moderately positive in mucinous differentiation areas of two cases (17).

The SPT24 clone has a stronger affinity for TTF-1 protein but may lead to TTF-1 positivity in cancer cells other than pulmonary and thyroid carcinomas. Another explanation may be the aberrant expression in these small cells caused by amplification of the chromosomal region of the TTF-1 gene (18).

TTF-1 positivity was previously reported in small cell prostate adenocarcinomas along with other neuroendocrine markers as reported by Yao and Agoff $(9,19)$. However, Ordonez et al. reported on the contrary (20). To our knowledge there is no information in the literature regarding TTF-1 positivity of this particular variant. Additionally TTF-1 positivity may serve as a surrogate marker for this particular variant of intraductal carcinoma. This observation should be supported by future studies.

\section{REFERENCES}

1. Cohen RJ, McNeal JE, Baillie T. Patterns of differentiation and proliferation in intraductal carcinoma of the prostate: Significance for cancer progression. Prostate. 2000; 43:11-9.

2. McNeal JE, Reese JH, Redwine EA, Freiha FS, Stamey TA. Cribriform adenocarcinoma of the prostate. Cancer. 1986; 58:1714-9.

3. McNeal JE, Yemoto CE. Spread of adenocarcinoma within prostatic ducts and acini. Morphologic and clinical correlations. Am J Surg Pathol. 1996; 20:802-14.

4. Rubin MA, de La Taille A, Bagiella E, Olsson CA, O’Toole KM. Cribriform carcinoma of the prostate and cribriform prostatic intraepithelial neoplasia: Incidence and clinical implications. Am J Surg Pathol. 1998;22:840-8.

5. Wilcox G, Soh S, Chakraborty S, Scardino PT, Wheeler TM. Patterns of high-grade prostatic intraepithelial neoplasia associated with clinically aggressive prostate cancer. Hum Pathol. 1998; 29:1119-23.

6. Guo CC, Epstein JI. Intraductal carcinoma of the prostate on needle biopsy: Histologic features and clinical significance. Mod Pathol. 2006;19:1528-35.

7. Wang W, Epstein JI. Small cell carcinoma of the prostate. A morphologic and immunohistochemical study of 95 cases. Am J Surg Pathol. 2008;32:65-71.

8. Capizzello A, Peponi E, Simou N, Ntaskagiannis D, Tasiou I, Kamina S, Tsekeris P. Pure small cell carcinoma of the prostate: A case report and literature review. Case Rep Oncol. 2011;16;4:8895.

9. Yao JL, Madeb R, Bourne P, Lei J, Yang X, Tickoo S, Liu Z, Tan D, Cheng L, Hatem F, Huang J, Anthony di Sant’Agnese P. Small cell carcinoma of the prostate: An immunohistochemical study. Am J Surg Pathol. 2006; 30:705-12.

10. Kovi J, Jackson MA, Heshmat MY. Ductal spread in prostatic carcinoma. Cancer. 1985: 56:1566-73.

11. Dawkins HJ, Sellner LN, Turbett GR, Thompson CA, Redmond SL, McNeal JE, Cohen RJ. Distinction between intraductal carcinoma of the prostate (IDC-P), high-grade dysplasia (PIN), and invasive prostatic adenocarcinoma, using molecular markers of cancer progression. Prostate. 2000;44:265-70.

12. Tomlins SA, Rhodes DR, Perner S, Dhanasekaran SM, Mehra R, Sun XW, Varambally S, Cao X, Tchinda J, Kuefer R, Lee C, Montie JE, Shah RB, Pienta KJ, Rubin MA, Chinnaiyan AM. Recurrent fusion of TMPRSS2 and ETS transcription factor genes in prostate cancer. Science. 2005;310:644-8.

13. Tomlins SA, Mehra R, Rhodes DR, Smith LR, Roulston D, Helgeson BE, Cao X, Wei JT, Rubin MA, Shah RB, Chinnaiyan AM. TMPRSS2:ETV4 gene fusions define a third molecular subtype of prostate cancer. Cancer Res. 2006; 66:3396-4000.

14. Guo CC, Zuo G, Cao D, Troncoso P, Czerniak BA. Prostate cancer of transition zone origin lacks TMPRSS2-ERG gene fusion. Mod Pathol. 2009; 22:866-71.

15. Cohen RJ, Shannon BA, Weinstein SL. Intraductal carcinoma of the prostate gland with transmucosal spread to the seminal vesicle: A lesion distinct from high-grade prostatic intraepithelial neoplasia. Arch Pathol Lab Med. 2007;131:1122-5. 
16. Cohen RJ, Wheeler TM, Bonkhoff H, Rubin MA. A proposal on the identification, histologic reporting, and implications of intraductal prostatic carcinoma. Arch Pathol Lab Med. 2007;131:1103-9.

17. Leite KR, Mitteldorf CA, Srougi M, Dall'oglio MF, Antunes AA, Pontes J Jr, Camara-Lopes LH. Cdx2, cytokeratin 20, thyroid transcription factor 1 , and prostate-specific antigen expression in unusual subtypes of prostate cancer. Ann of Diagn Pathol. 2008;12:260-6.

18. Comperat E, Zhangi F, Perrotin C, Molina T, Magdeleinat P, Marmey B, Regnard JF, Audouin J, Camilleri-Broet S. Variable sensitivity and specificity of TTF-1 antibodies in lung metastatic adenocarcinoma of colorectal origin. Mod Pathol. 2005;18:13716.
19. Agoff SN, Lamps LW, Philip AT, Amin MB, Schmidt RA, True LD, Folpe AL. Thyroid transcription factor- 1 is expressed in extrapulmonary small cell carcinomas but not in other extrapulmonary neuroendocrine tumors. Mod Pathol 2000;13:238-42.

20. Ordonez NG. Value of thyroid transcription factor-1 immunostaining in distinguishing small cell lung carcinomas from other small cell carcinomas. Am J Surg Pathol. 2000;24: 1217-23. 